\title{
Anodically generated manganese(III) sulphate for the oxidation of dipeptides in aqueous sulphuric acid medium: A kinetic study
}

\author{
M N KUMARA ${ }^{1}$, D CHANNE GOWDA ${ }^{1}$, A THIMME GOWDA ${ }^{2}$ and K S RANGAPPA ${ }^{1, *}$ \\ ${ }^{1}$ Department of Studies in Chemistry, University of Mysore, Manasagangothri, My sore 570 006, India \\ ${ }^{2}$ Department of Chemistry, AVK College for Women, Hassan 573 201, India \\ e-mail: rangappaks@yahoo.com
}

MS received 17 May 2001; revised 21 June 2003

\begin{abstract}
The kinetic of oxidation of dipeptides (DP) namely valyl-glycine (Val-Gly), alanyl-glycine (Ala-Gly) and glycyl-glycine (Gly-Gly), by $\mathrm{Mn}$ (III) have been studied in the presence of sulphate ions in acid medium at $26^{\circ} \mathrm{C}$. The reaction was followed spectrophotometrically at $\lambda_{\max }=500 \mathrm{~nm}$. A firstorder dependence of the rate on both $[\mathrm{Mn}(\mathrm{III})]_{\mathrm{o}}$ and $[\mathrm{DP}]_{\mathrm{o}}$ was observed. The rate is independent of the concentration of reduction product, $\mathrm{Mn}$ (II) and hydrogen ions. The effects of varying the dielectric constant of the medium and addition of anions such as sulphate, chloride and perchlorate were studied. The activation parameters have been evaluated using Arrhenius and Eyring plots. The oxidation products were isolated and characterized. A mechanism involving the reaction of DP with $\mathrm{Mn}$ (III) in the ratelimiting step is suggested. An apparent correlation was noted between the rate of oxidation and the hydrophobicity of these dimers, where increased hyphobicity results in increased rate of oxidation.
\end{abstract}

Keywords. Oxidation; dipeptides; manganese(III).

\section{Introduction}

There has been a great deal of attention focussed on the oxidation of organic substrates by high-valent metal ions. Of these, manganese(III) oxidation is of special importance due to its biological relevance. ${ }^{1}$ Manganese(III) porphyrins have been studied as possible models for closely related biologically significant systems. ${ }^{2}$ Some studies have been reported on the kinetics of manganese(III) oxidation of various substrates in perchlorate, sulphate, acetate and pyrophosphate medium. ${ }^{3,4}$ Peptides and proteins are the most characteristic chemical compounds found in living cells. Peptides, such as enkephalins, oxytocin, vasopressin, leutinizing hormone releasing hormone (LHRH), opioid peptides and elastic sequence play a very important role in biology. These peptides are susceptible to enzymes. Extensive work has been reportted on the enzymatic degradation of these peptides. Although the kinetics of oxidation of amino acids with various metal ions and halogens ${ }^{5,6}$ in acid and alkaline media has been studied, oxida-

*For correspondence tion of these biologically active peptides have not been reported in literature.

We have synthesised three dipeptides viz. valylglycine (Val-Gly), alanyl-glycine (Ala-Gly) and glycyl-glycine (Gly-Gly) which are fragments of elastic sequences ${ }^{7}$ to study the kinetics of oxidation with $\mathrm{Mn}(\mathrm{III})$ in acid medium at $26^{\circ} \mathrm{C}$ to elucidate the mechanism of these redox reactions.

\section{Peptide synthesis}

All of the amino acids used except glycine are of L-configuration unless otherwise specified. All $t$-butyloxycarbonyl (Boc) amino acids, amino acid derivatives, 1-ethyl-3(3-dimethylaminopropyl)carbodiimide (EDCI), 1-hydroxybenzotriazole (HOBt), trifluroacetic acid (TFA) and N-methylmorpholine (NMM) were purchased from Advanced Chem. Tech. (Louisville, KY, USA). All solvents and reagents were of analytical grade or were purified according to procedures recommended for peptide synthesis. Thin layer chromatography (TLC) was carried out on silica gel plates obtained from Whatman Inc., with the following solvent systems: chloroform-methanol- 
acetic acid (95:5:3), $R_{f}^{1}$; chloroform-methanolacetic acid (90:10:3), $R_{f}^{2}$, and chloroform-methanolacetic acid $(85: 15: 3), R_{f}$. The compounds on TLC plates were detected by UV light after spraying with ninhydrin or by chlorine/toluidine. The melting points were determined by using Thomas-Hoover melting point apparatus and are uncorrected.

\subsection{Boc- $X_{a a}-G l y-O b z l\left[X_{a a}=\right.$ Val or Ala or Gly]}

Boc- $\mathrm{X}_{a a}(0.02 \mathrm{~mol})$ and HOBt $(3.37 \mathrm{~g}, 0.022 \mathrm{~mol})$ in DMF (40 ml) was cooled to $-15 \pm 1^{\circ} \mathrm{C}$ and EDCI $(4.21 \mathrm{~g}, 0.022 \mathrm{~mol})$ was added. After stirring for $20 \mathrm{~min}$, a pre-cooled solution of Gly-OBzl.Tos $(6.78 \mathrm{~g}, 0.02 \mathrm{~mol})$ and NMM $(2.4 \mathrm{ml}, 0.022 \mathrm{~mol})$ in DMF $(50 \mathrm{ml})$ was added and stirred overnight at room temperature. After evaporating DMF under reduced pressure, the residue was taken up by chloroform and extracted with $10 \%$ citric acid, water, $5 \%$ sodium bicarbonate, water and dried over sodium sulphate. The solvent was removed under reduced pressure and recrystallized from ether/ethyl acetate to obtain $6.34 \mathrm{~g}(87 \%)$ of Boc-X $a a^{-G l y-O B z l . ~} R_{f}^{1}$ $0.58, R_{f}^{2} 0.72$ and $R_{f}^{3} 0.66$, m.p. $80^{\circ} \mathrm{C}\left(l_{i t}^{8} 80-82^{\circ} \mathrm{C}\right)$; $6.0 \mathrm{~g}(93 \%)$ of Boc-X $\mathrm{X}_{a a}$-Gly-OBzl. $R_{f}^{1} 0.51$ and $R_{f}^{2}$ 0.63, m.p. $89-90^{\circ} \mathrm{C}\left(\right.$ lit $\left.^{8} 90-92^{\circ} \mathrm{C}\right)$ and $5.7 \mathrm{~g}(89 \%)$ of Boc-X ${ }_{a a}-\mathrm{Gly}-\mathrm{OBzl} . R_{f}^{1} \quad 0.49$ and $R_{f}^{2} \quad 0.58$, m.p. $81-82^{\circ} \mathrm{C}\left(\right.$ lit $\left.^{9} 82-83^{\circ} \mathrm{C}\right)$.

\section{$2.2 X_{a a}-G l y$}

Boc- $\mathrm{X}_{a a}-$ Gly-OBzl $(0.015 \mathrm{~mol})$ was saponified in methanol $(50 \mathrm{ml})$ using $1 \mathrm{M} \mathrm{NaOH}(2.0$ equiv.) for $2 \mathrm{~h}$ at room temperature. After evaporating the solvent under reduced pressure, the residue was taken up by water and washed with chloroform $(3 \times$ $25 \mathrm{ml}$ ). The aqueous layer was cooled and neutralized with cold $1 \mathrm{M} \mathrm{HCl}$ and extracted with chloroform $(40 \mathrm{ml})$. The organic phase was washed with cold $0.1 \mathrm{M} \mathrm{HCl}, 50 \%$ saturated $\mathrm{NaCl}$ and dried over $\mathrm{Na}_{2} \mathrm{SO}_{4}$. The solvent was removed in vacuo and triturated with ether, filtered, washed with ether and dried to obtain $3.78 \mathrm{~g}$ (92\%) of Boc-Val-Gly-OH. $R_{f}^{2} 0.22$ and $R_{f}^{3} 0.34 ; 3.4 \mathrm{~g}(92.1 \%)$ of Boc- $\mathrm{X}_{a a}-\mathrm{Gly}-$ OH. $R_{f}^{2} 0.24$ and $R_{f}^{3} 0.35$ and $3.15 \mathrm{~g}(90.5 \%)$ of Boc$\mathrm{X}_{a a}$-Gly-OH. $R_{f}^{2} 0 \cdot 26$ and $R_{f}^{3} 0 \cdot 37$.

Boc- $\mathrm{X}_{a a}-\mathrm{Gly}-\mathrm{OH}$ (0.01 mol) was deblocked with TFA $(10 \mathrm{ml} / \mathrm{g}$ of peptide) by stirring for $40 \mathrm{~min}$. The solvent was removed under reduced pressure, the residue was triturated with ether, filtered, washed with ether to obtain TFA. $\mathrm{X}_{a a}$-Gly-OH (100\%).

\section{Kinetic measurements}

\subsection{Preparation of Mn(III) sulphate}

A $0.05 \mathrm{M}$ solution of manganese(III) sulphate was prepared $^{10}$ using the standard anodic oxidation of $0.2 \mathrm{M}$ solution of manganese(II) sulphate in $5 \mathrm{M}$ sulphuric acid performed in an undivided cell with a platinum foil anode (generation area $4.0 \mathrm{~cm}^{2}$ ) and a thin platinum spiral cathode (effective area $0 \cdot 2 \mathrm{~cm}^{2}$ ). The manganese(III) sulphate solution contained an excess but known concentration of manganese(II) sulphate to suppress the disproportionation reaction,

$$
2 \mathrm{Mn}(\mathrm{III}) \rightleftharpoons \mathrm{Mn}(\mathrm{II})+\mathrm{Mn}(\mathrm{IV}) .
$$

Though the solution appeared to be stable for more than a month at $\left[\mathrm{H}^{+}\right]>5.0 \mathrm{M}$, solution of manganese(III) sulphate prepared afresh daily was used in the experiments. All other reagents were prepared from AR grade chemicals. Triply distilled water was used for preparing aqueous solutions.

\subsection{Experimental}

Solutions containing the requisite amounts of DP, sulphuric acid (to maintain known acid concentration), manganese(II) sulphate and water (to keep the total volume constant) were placed in stopperd boiling tube. The mixtures were thermally equilibrated in a water bath at $26^{\circ} \mathrm{C}$. To the solutions in each tube, was added an aliquot of pre-equilibrated manganese(III) sulphate stock solution to give a known overall concentration. The progress of the reaction was monitored for two half-lives by measuring the absorbance of unreacted $\mathrm{Mn}(\mathrm{III})$ at $500 \mathrm{~nm}$ using a Spectrochem MK II spectrophotometer. The reaction mixture was quenched iodometrically. Plots of $\log$ (absorbance) vs. time were linear. The rate constants, $k_{\text {obs }}$, calculated from these plots were reproducible within $\pm 3 \%$ error.

\section{Stoichiometry}

The mixtures containing DP (0.001 M), acid ( $0 \cdot 1 \mathrm{M})$ and excess $\mathrm{Mn}(\mathrm{III})(0.005 \mathrm{M})$ were kept for $24 \mathrm{~h}$ at 
$26^{\circ} \mathrm{C}$. The unconsumed $\mathrm{Mn}(\mathrm{III})$ was then determined iodometrically. Four moles of oxidant were sufficient to oxidise one mole of DP leading to aldehydes, carbon dioxide, ammonia and Mn(II).

Based on the experimental results, the following stoichiometric equations are shown below.

$$
\begin{aligned}
& \text { Val-Gly } \\
& \mathrm{H}_{2} \mathrm{~N}-\mathrm{CH}\left[\mathrm{CH}\left(\mathrm{CH}_{3}\right)_{2}\right] \mathrm{CO}-\mathrm{NH}-\mathrm{CH}_{2}-\mathrm{COOH}+ \\
& 2 \mathrm{Mn}^{3+}+2 \mathrm{Mn}(\mathrm{OH})^{2+}+\mathrm{H}_{2} \mathrm{O} \rightarrow\left(\mathrm{CH}_{3}\right)_{2} \mathrm{CHCHO}+ \\
& \mathrm{HCHO}+2 \mathrm{CO}_{2}+2 \mathrm{NH}_{4}^{+}+4 \mathrm{Mn}^{2+} .
\end{aligned}
$$

$$
\begin{aligned}
& \text { Ala-Gly } \\
& \qquad \begin{array}{l}
\mathrm{H}_{2} \mathrm{~N}-\mathrm{CH}\left(\mathrm{CH}_{3}\right) \mathrm{CO}-\mathrm{NH}-\mathrm{CH}_{2}-\mathrm{COOH}+2 \mathrm{Mn}^{3+}+ \\
2 \mathrm{Mn}(\mathrm{OH})^{2+}+\mathrm{H}_{2} \mathrm{O} \rightarrow \mathrm{CH}_{3} \mathrm{CHO}+\mathrm{HCHO}+ \\
\quad 2 \mathrm{CO}_{2}+2 \mathrm{NH}_{4}^{+}+4 \mathrm{Mn}^{2+} .
\end{array}
\end{aligned}
$$

$$
\begin{aligned}
& \text { Gly-Gly } \\
& \mathrm{H}_{2} \mathrm{~N}-\mathrm{CH}_{2}-\mathrm{CO}-\mathrm{NH}-\mathrm{CH}_{2}-\mathrm{COOH}+2 \mathrm{Mn}^{3+}+ \\
& 2 \mathrm{Mn}(\mathrm{OH})^{2+}+\mathrm{H}_{2} \mathrm{O} \rightarrow 2 \mathrm{HCHO}+2 \mathrm{CO}_{2}+2 \mathrm{NH}_{4}^{+}+ \\
& 4 \mathrm{Mn}^{2+} .
\end{aligned}
$$

\section{Product analysis}

After the reaction was completed, the reaction products were extracted with ether and subjected to column chromatography on silica gel (60-200 mesh) using gradient elution (dichloromethane to chloroform). After initial separation, the products were further purified by recrystallization. Aldehydes were quantified in the ether extract by the formation of 2,4-dinitrophenylhydrazone (DNP) derivatives isolable up to $95 \%$ yield. Ammonia and $\mathrm{CO}_{2}$ were detected by the conventional tests.

\section{Results and discussion}

All kinetic runs were performed under pseudo firstorder conditions of $[\mathrm{DP}] \gg[\mathrm{Mn}(\mathrm{III})]$. Plots of $\log$ [Mn(III)] vs time were linear $(r>0.998)$ even beyond $75 \%$ of the reaction, showing first-order dependence of the rate on $[\mathrm{Mn}(\mathrm{III})]$ (table 1). At constant $[\mathrm{Mn}(\mathrm{III})]_{\mathrm{o}},[\mathrm{Mn}(\mathrm{II})]_{\mathrm{o}},\left[\mathrm{H}_{2} \mathrm{SO}_{4}\right],\left[\mathrm{Na}_{2} \mathrm{SO}_{4}\right]$ and temperature, the rate increased with increase in [DP] $]_{\mathrm{o}}$ (table 1). Plots of $\log k_{\mathrm{obs}}$ vs $\log [\mathrm{DP}]_{\mathrm{o}}$ were linear with slopes of $0.99,1.00$ and 1.06 for ValGly, Ala-Gly and Gly-Gly respectively. Increase in

\begin{tabular}{|c|c|c|c|c|}
\hline \multirow{2}{*}{$\begin{array}{l}{[\mathrm{Mn}(\mathrm{III})]} \\
\left(10^{3} \mathrm{M}\right)\end{array}$} & \multirow{2}{*}{$\begin{array}{c}{[\mathrm{DP}]} \\
\left(10^{2} \mathrm{M}\right)\end{array}$} & \multicolumn{3}{|c|}{$k_{\mathrm{obs}} \times 10^{5}\left(\mathrm{~s}^{-1}\right)$} \\
\hline & & Val-Gly & Ala-Gly & Gly-Gly \\
\hline $0 \cdot 6$ & $1 \cdot 0$ & 4.73 & $3 \cdot 59$ & $2 \cdot 63$ \\
\hline $0 \cdot 8$ & 1.0 & $4 \cdot 80$ & $3 \cdot 50$ & $2 \cdot 61$ \\
\hline $1 \cdot 0$ & $1 \cdot 0$ & $4 \cdot 75$ & 3.59 & $2 \cdot 63$ \\
\hline $1 \cdot 2$ & $1 \cdot 0$ & $4 \cdot 60$ & $3 \cdot 40$ & $2 \cdot 55$ \\
\hline $1 \cdot 4$ & $1 \cdot 0$ & $4 \cdot 55$ & $3 \cdot 60$ & $2 \cdot 70$ \\
\hline 1.6 & $1 \cdot 0$ & $4 \cdot 49$ & $3 \cdot 72$ & $2 \cdot 69$ \\
\hline $1 \cdot 8$ & $1 \cdot 0$ & $4 \cdot 90$ & $3 \cdot 85$ & $2 \cdot 61$ \\
\hline $1 \cdot 0$ & 0.6 & $2 \cdot 82$ & 1.91 & $1 \cdot 54$ \\
\hline $1 \cdot 0$ & $0 \cdot 8$ & $3 \cdot 76$ & $2 \cdot 55$ & $2 \cdot 07$ \\
\hline $1 \cdot 0$ & $1 \cdot 0$ & $4 \cdot 75$ & $3 \cdot 59$ & $2 \cdot 63$ \\
\hline $1 \cdot 0$ & $1 \cdot 2$ & 5.63 & $3 \cdot 86$ & $3 \cdot 20$ \\
\hline $1 \cdot 0$ & 1.4 & $6 \cdot 54$ & $4 \cdot 48$ & 3.72 \\
\hline $1 \cdot 0$ & $1 \cdot 6$ & $7 \cdot 50$ & $5 \cdot 08$ & $4 \cdot 32$ \\
\hline $1 \cdot 0$ & $1 \cdot 8$ & 8.42 & $5 \cdot 76$ & 4.90 \\
\hline
\end{tabular}
$\left[\mathrm{H}^{+}\right](0.6$ to $1.8 \mathrm{M})$, had no effect on the rate, [Mn(II)] (0.006 to $0.016 \mathrm{M}), \mathrm{Cl}^{-}(0.001$ to $0.01 \mathrm{M})$, $\mathrm{SO}_{4}^{2-}(0.001$ to $0.01 \mathrm{M})$ and $\mathrm{ClO}_{4}^{-}(0.001$ to $0.01 \mathrm{M})$ on the rate were insignificant. The reaction product

\begin{tabular}{|c|c|c|c|c|c|}
\hline \multirow{2}{*}{$\begin{array}{l}\mathrm{I} \\
\mathrm{MeOH} \\
(\% v / v)\end{array}$} & \multicolumn{2}{|c|}{ Dielectric constant } & \multicolumn{3}{|c|}{$k_{\mathrm{obs}} \times 10^{5}\left(\mathrm{~s}^{-1}\right)$} \\
\hline & (D) & $10^{3} / \mathrm{D}$ & Val-Gly & Ala-Gly & Gly-Gly \\
\hline 0 & $76 \cdot 73$ & $13 \cdot 00$ & $4 \cdot 75$ & $3 \cdot 49$ & $2 \cdot 63$ \\
\hline 10 & $72 \cdot 37$ & $13 \cdot 80$ & 8.94 & $5 \cdot 50$ & 3.64 \\
\hline 20 & $67 \cdot 48$ & $14 \cdot 80$ & $11 \cdot 52$ & $9 \cdot 36$ & $5 \cdot 76$ \\
\hline 30 & 62.71 & 14.40 & 15.90 & $16 \cdot 64$ & 9.00 \\
\hline 40 & $58 \cdot 06$ & $17 \cdot 80$ & $17 \cdot 20$ & $32 \cdot 50$ & $16 \cdot 00$ \\
\hline
\end{tabular}

Mn(II) had no effect on the reaction, indicating that the product is not involved in a pre-equilibrium with the oxidant.

The solvent composition of the medium was varied by adding methanol ( 0.0 to $40 \%)$ to the reaction

Table 1. Effect of varying reactants concentration on the rate ${ }^{\mathrm{a}}$.

${ }^{\mathrm{a}}[\mathrm{Mn}(\mathrm{II})]_{\mathrm{o}}=0.01 \mathrm{M},\left[\mathrm{H}_{2} \mathrm{SO}_{4}\right]=0 \cdot 1 \mathrm{M}$, at $26^{\circ} \mathrm{C}$

Table 2. Effect of varying dielectric constant (D) on the rate ${ }^{\mathrm{a}}$.

${ }^{\mathrm{a}}[\mathrm{Mn}(\mathrm{III})]_{\mathrm{o}}=0.001 \mathrm{M}, \quad[\mathrm{DP}]_{\mathrm{o}}=0.01 \mathrm{M}, \quad[\mathrm{Mn}(\mathrm{II})]_{\mathrm{o}}=$ $0.01 \mathrm{M},\left[\mathrm{H}_{2} \mathrm{SO}_{4}\right]=0.1 \mathrm{M}$, at $26^{\circ} \mathrm{C}$

Table 3. Temperature dependence of the oxidation of DP by $\mathrm{Mn}(\mathrm{III})^{\mathrm{a}}$.

\begin{tabular}{lccccr}
\hline & \multicolumn{5}{c}{$k_{\text {obs }} \times 10^{5}\left(\mathrm{~s}^{-1}\right)$ at temp $(\mathrm{K})$} \\
\cline { 2 - 6 } Substrate & 294 & 299 & 304 & 309 & \multicolumn{1}{c}{314} \\
\hline Val-Gly & 3.50 & 4.75 & 6.10 & 8.00 & 12.02 \\
Ala-Gly & 2.76 & 3.59 & 4.92 & 6.46 & 8.72 \\
Gly-Gly & 2.01 & 2.63 & 3.39 & 4.27 & 5.63 \\
\hline
\end{tabular}

${ }^{\mathrm{a}}[\mathrm{Mn}(\mathrm{III})]_{\mathrm{o}}=0.001 \mathrm{M}, \quad[\mathrm{DP}]_{\mathrm{o}}=0.01 \mathrm{M}, \quad[\mathrm{Mn}(\mathrm{II})]_{\mathrm{o}}=0.01 \mathrm{M}$, $\left[\mathrm{H}_{2} \mathrm{SO}_{4}\right]=0 \cdot 1 \mathrm{M}$ 
Table 4. Activation parameters for the oxidation of DP by $\mathrm{Mn}(\mathrm{III})^{\mathrm{a}}$.

\begin{tabular}{lccccc}
\hline & $E_{a}$ & $\Delta H^{\#}$ & $\Delta S^{\#}$ & \multicolumn{1}{c}{$\Delta G^{\#}$} & \\
\cline { 2 - 5 } Substrate & $\left(\mathrm{k} \mathrm{J} \mathrm{mol}^{-1}\right)$ & $\left(\mathrm{k} \mathrm{J} \mathrm{mol}^{-1}\right)$ & $\left(\mathrm{J} \mathrm{K}^{-1} \mathrm{~mol}^{-1}\right)$ & $\left(\mathrm{k} \mathrm{J} \mathrm{mol}^{-1}\right)$ & $\log A$ \\
\hline Val-Gly & 42.75 & $40 \cdot 22$ & $-192 \cdot 82$ & $97 \cdot 86$ & 31 \\
Ala-Gly & 44.72 & 41.94 & -189.29 & 99.47 & 3.3 \\
Gly-Gly & 40.26 & 37.74 & $-206 \cdot 19$ & 99.99 & 2.4 \\
\hline
\end{tabular}

${ }^{\mathrm{a}}[\mathrm{Mn}(\mathrm{III})]_{\mathrm{o}}=0.001 \mathrm{M},[\mathrm{DP}]_{\mathrm{o}}=0.01 \mathrm{M},[\mathrm{Mn}(\mathrm{II})]_{\mathrm{o}}=0.01 \mathrm{M},\left[\mathrm{H}_{2} \mathrm{SO}_{4}\right]=0.1 \mathrm{M}$

mixture. The rate increases with increase in methanol content (table 2). The plots of $\log k_{\mathrm{obs}}$ vs $1 / D$ ( $D=$ dielectric constant of the medium) were linear $(r=0.999)$ with positive slopes. Measurements of rate constants were done both in the presence and absence of dipeptides with $\mathrm{Mn}$ (III) and the rate constants were taken for the calculation of effective $k_{\text {obs }}$, although the rate of oxidation of methanol in the absence of DP is negligible under the present conditions employed.

To determine the activation parameters, the reactions were carried out at different temperatures (21$41^{\circ} \mathrm{C}$ ). The Arrhenius plots of $\log k_{\mathrm{obs}}$ vs $1 / T$ (table $3)$, were found to be linear $(r=0.999)$. The activation energies $\left(E_{a}\right)$ were calculated from the slope of the plots. From this value, the activation parameters, $\Delta H^{\#}, \Delta S^{\#}, \Delta G^{\#}$ and the frequency factor $(\log A$ ) (table 4), were evaluated.

Addition of acrylamide to the reaction mixture did not cause polymerization suggesting the absence of free-radical involvement during the oxidation.

Data published by Diebler, Sutin ${ }^{11}$, Fackler and Chawla $^{12}$ and Wells ${ }^{13}$, have shown that in the presence of $F^{-}$ion, aqueous solution of Mn(III) sulphate consists of hexaquomanganese(III), $\mathrm{Mn}(\mathrm{III})_{(\mathrm{aq})}$, $\mathrm{Mn}(\mathrm{OH})_{(\mathrm{aq})}^{2+}$ and $\mathrm{MnF}_{(\mathrm{aq})}^{2+}$. Along the same line it can be assumed with jus-tification that $\mathrm{Mn}$ (III) species present in sulphuric acid solution are $\mathrm{Mn}(\mathrm{III})_{(\mathrm{aq})}$, $\mathrm{Mn}(\mathrm{OH})_{\text {(aq) }}^{2+}$ and $\mathrm{MnSO}_{(4 \mathrm{aq})}^{+}$. Therefore, it was shown ${ }^{14}$ that manganese(III) sulphate in aqueous sulphuric acid solution contains $\mathrm{Mn}_{(\mathrm{aq})}^{3+}$ and $\mathrm{Mn}(\mathrm{OH})_{(\mathrm{aq})}^{2+}$ as reactive species.

$$
\mathrm{Mn}_{(\mathrm{aq})}^{3+}+\mathrm{H}_{2} \mathrm{O} \stackrel{K_{h}}{\rightleftharpoons} \mathrm{Mn}(\mathrm{OH})_{(\mathrm{aq})}^{2+}+\mathrm{H}^{+} .
$$

The hydrolysis constant of manganese(III) sulphate calculated was $k_{h}=0.93 \pm 0.03$ at $25^{\circ} \mathrm{C}$. The absorption spectra of both $\mathrm{Mn}_{(\text {aq) }}^{3+}$ and $\mathrm{Mn}(\mathrm{OH})_{(\mathrm{aq})}^{2+}$ have been reported to be similar in both the visible and UVregion. Our observation of the electronic absorption spectra is consistent with the values reported. Kinetic studies have shown that $\mathrm{Mn}_{(\mathrm{aq})}^{3+}$ is more reactive. Formation of dihydroxo species $\mathrm{Mn}(\mathrm{OH})_{2(\text { aq) }}^{+}$, produced by further hydrolysis of $\mathrm{Mn}(\mathrm{OH})_{(\mathrm{aq})}^{2+}$ is another possibility. ${ }^{15}$

$$
\mathrm{Mn}(\mathrm{OH})_{(\text {aq })}^{2+}+\mathrm{H}_{2} \mathrm{O} \rightarrow \mathrm{Mn}(\mathrm{OH})_{2(\mathrm{aq})}^{+}+\mathrm{H}^{+} .
$$

However, a fresh solution of manganese(III) sulphate is always prepared and used immediately after cessation of the electrolysis, thereby eliminating any reaction due to $\mathrm{Mn}(\mathrm{OH})_{2(\mathrm{aq})}^{+}$. The molar absorption coefficient, ' $\varepsilon$ ' ranges between $131-110 \mathrm{M}^{-1} \mathrm{~cm}^{-1}$ at $\left[\mathrm{H}^{+}\right]=1.20-2.50(\mathrm{M})$. The high value of ' $\varepsilon$ ' has been attributed to the presence of hydrolyzed species $\mathrm{Mn}(\mathrm{OH})_{(\mathrm{aq})}^{2+}$. Since there is no hydrogen ion dependence on the rate, this suggests that $\mathrm{Mn}(\mathrm{OH})_{(\mathrm{aq})}^{2+}$ is not the reactive species. The absence of a sulphate effect on the reaction rate indicates that $\mathrm{MnSO}_{4 \text { (aq) }}^{+}$ is not the active species in the present condition. Therefore, $\mathrm{Mn}(\mathrm{OH})_{(\mathrm{aq})}^{2+}$ and $\mathrm{Mn}_{(\mathrm{aq})}^{3+}$ are the reactive species as shown in the mechanism.

Scheme 1 accounts for the observed experimental results.

Amis $^{16}$ has shown that plots of $\log k_{\text {obs }}$ vs $1 / D$ gives a straight line with a positive slope for positive ion-dipole interaction. The positive dielectric effect in the present investigation shows charge dispersal in the transition state, pointing towards a positive ion-dipole reaction and hence supports the scheme in scheme 2.

$$
\mathrm{Mn}(\mathrm{OH})_{(\mathrm{aq})}^{2+}+\mathrm{DP} \stackrel{k_{1}}{\longrightarrow} X
$$

(i) slow and rate determining step,

$X \stackrel{k_{2}}{\longrightarrow}$ products, (ii) fast.

Hence, rate $=k_{1}\left[\mathrm{Mn}(\mathrm{OH})^{2+}\right][\mathrm{DP}]$.

Scheme 1. 


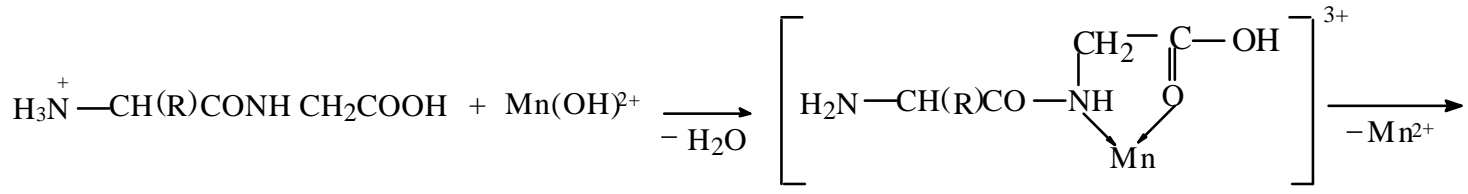

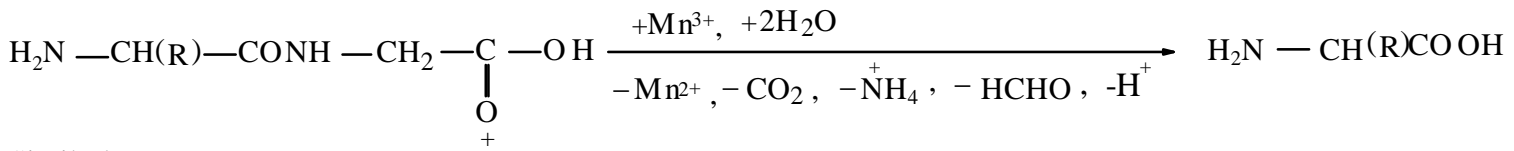

$$
\begin{aligned}
& \text { Similarly, }
\end{aligned}
$$

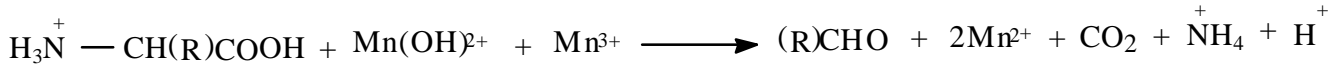

$$
\begin{aligned}
& \mathrm{R}=\left(\mathrm{CH}_{3}\right)_{2} \mathrm{CH}-\text { for Val-Gly; } \mathrm{R}=\mathrm{CH}_{3}-\text { for Ala-Gly and } \mathrm{R}=\mathrm{H}-\text { for Gly-Gly }
\end{aligned}
$$

Scheme 2.

Table 5. Deviations in peak wavelengths and absorbance.

\begin{tabular}{lccccc}
\hline Substrate & $\begin{array}{c}\lambda_{\max } \\
(\mathrm{nm})\end{array}$ & Abs & Complex & $\begin{array}{c}\lambda_{\max } \\
(\mathrm{nm})\end{array}$ & Abs \\
\hline Mn(III) & 500 & $0 \cdot 97$ & & & \\
Val-Gly & 232 & $2 \cdot 48$ & Mn(III) + Val-Gly & 437 & $2 \cdot 60$ \\
Ala-Gly & 229 & $2 \cdot 46$ & Mn(III) + Ala-Gly & 430 & $2 \cdot 63$ \\
Gly-Gly & 224 & $2 \cdot 45$ & Mn(III) + Gly-Gly & 445 & $2 \cdot 70$ \\
\hline
\end{tabular}

The rate of oxidation of dipeptides by $\mathrm{Mn}$ (III) was compared with that of oxidation of amino-acids, Val, Ala, and Gly and it was found that the rate of oxidation of dipeptide was slower than free aminoacids. The change is due to the increased difference between the functional groups and consequently weaker electrostatic effects. Hence, the oxidation of dipeptides is expected to be slower than the monomers. Further, an apparent correlation was noted between the rate of oxidation and the hydrophobicity of these sequences, where increased hydrophobicity results in increased rate of oxidation. The order of oxidation of dipeptides was found to Val-Gly $>$ Ala-Gly > Gly-Gly, which is in well agreement with their hydrophobicity. ${ }^{17}$

\subsection{Spectral evidence for the formation of DP-Mn(III) complexes}

The study of UV-Visible spectra separately, of pure Mn(III), DP (Val-Gly, Ala-Gly and Gly-Gly) and mixtures of $\mathrm{Mn}(\mathrm{III})$ and DP show deviations in peak wave length and absorbance as in table 5. It is noted that the values of the complexes are different from each of the substrate and Mn(III) in its pure form.

\section{Acknowledgements}

KSR is grateful to the All India Council of Technical Education (AICTE), Government of India, New Delhi, for financial support. ATG the thanks University Grants Commission, New Delhi for financial support.

\section{References}

1. Boucher J 1972 Coord. Chem. Rev. 7289

2. Carlvin M 1965 Rev. Pure. Appl. Chem. 151

3. Davies G 1969 Coord. Chem. Rev. 4199

4. Rangappa K S, Chandraju S and Made Gowda N M 1998 Int. J. Chem. Kinet. 307

5. Mahadevappa D S, Ananda S, Made Gowda N M and Rangappa K S 1985 J. Chem. Soc., Perkin Trans. 2 39

6. Rangappa K S, Chandraju S and Mahadevappa D S 1996 Trans. Met. Chem. 21519

7. Urry D W 1993 Angew Chem., Int. Ed. Engl. 32819

8. Prasad K U, Iqbal M and Urry D W 1985 Int. J. Peptide Protein Res. 25408

9. Urry D W, Harris R D, Long M M and Prasad K U 1986 Int. J. Peptide Protein Res. 28649

10. Kamaluddin 1980 Indian J. Chem. A19 431

11. Diebler H and Sutin N 1964 J. Phys. Chem. 68174

12. Fackler J P and Chawla I D 1964 Inorg. Chem. Soc. 381130

13. Wells G F and Davies G A 1967 J. Chem. Soc. (A) 1858

14. Sherigara B S, Bhat K I, Pinto I and Made Gowda N M 1995 Int. J. Chem. Kinet. 27675

15. Sikos P A, Peterson N C and Huie R E 1984 Inorg. Chem. 231134

16. Amis E S 1953 Chem. Educ. 30351

17. Urry D W, Gowda D C, Parker T M, Luan C H, Reid M C, Harris C M, Pattanaik A and Harris R D 1993 Biopolymers 321243 